\title{
Urban Infrastructure for Development
}

\author{
Paul Collier \\ University of Oxford \\ Anthony J. Venables \\ University of Oxford
}

\begin{abstract}
This paper evaluates the importance of infrastructure - in particular infrastructure for connectivity - in the development of fast growing cities. It argues that the value of infrastructure goes well beyond the 'user-benefits' of standard cost-benefit appraisal, as infrastructure supports an economic environment in which the economic potential of cities - scale, specialisation, and agglomeration economies - can be achieved. It then turns to the policies that are required to support infrastructure investment, looking at public finance, governance, urban density, and turning finally to the wider national context.
\end{abstract}

Keywords: urban, infrastructure, connectivity, transport, Africa.

JEL classification: 018, 055, R4

\author{
Authors' Addresses: \\ P. Collier \\ Blavatnik School of Government, \\ Walton Street, \\ Oxford
}

\author{
Corresponding author \\ A.J. Venables \\ Department of Economics \\ Manor Road \\ Oxford OX1 3UQ UK \\ tony.venables@economics.ox.ac.uk
}




\section{Introduction}

Infrastructure is fundamentally concerned with the provision of connectivity and energy. In the OECD the problems posed by infrastructure investment have necessarily been surmounted: large investments in both types of infrastructure have enabled firms to be productive. Provision has been partly through public investment financed by taxation and public debt, and partly through private investment facilitated and circumscribed by regulation. In contrast, in most poor countries such infrastructure is grossly inadequate. Economic activities are disconnected from each other and from global markets, while energy is mispriced and underprovided. This inadequacy reflects a failure in both the public and the private means of provision.

The scope for private provision differs considerably between the various types of infrastructure. As demonstrated by prevailing practice in the OECD, the investments necessary for energy are potentially financeable entirely through the private sector. In contrast, much of the infrastructure needed for connectivity is best provided publicly. Some (such as roads) are public goods, use of which may be non-rival and access to which may be non-excludable. Many of the investments are 'lumpy', implying non-marginal changes and hence the creation of economic surplus that is not captured by suppliers. Some are responses to negative externalities (addressing congestion or sanitation in dense urban areas) and others, we suggest below, support positive externalities of agglomeration.

In this short paper we cannot be comprehensive. Since the policies for attracting private finance for infrastructure in developing countries have recently been reviewed in this journal (Estache et al. 2015), we focus on connectivity rather than energy, while to illustrate the order of magnitude of the infrastructure challenge, we focus on Africa (SSA). This is the region with the largest infrastructure deficit, and annual spending needs that have been estimated at around $\$ 90 \mathrm{bn}$ pa, amounting to $15 \%$ of African GDP or $\$ 120$ per capita each year, while actual spending is running at less than 2/3rds of this (Foster and Briceno-Garmendia 2010). Although the largest single component of this is power, connectivity needs are also very large, amounting to around $5 \%$ of GDP per annum (see table 1). One component of the infrastructure for connectivity is inter-urban, connecting economic activity across cities and to ports. However, it is urban areas that will see the largest needs, since the number of Africans living in cities is predicted to triple over the next 30 years. We therefore focus on the urban context, with some discussion of national transport issues towards the end of the paper.

The next section of the paper gives some background on African infrastructure, and section 3 lays out the arguments for the value of connectivity and the role of infrastructure in supporting that connectivity. We argue that the value of infrastructure goes well beyond the 'user-benefits' of standard cost-benefit appraisal as it supports an economic environment in which the economic potential of cities - scale, specialisation, and agglomeration economies - can be achieved. 
Section 4 turns to the policies that are required to support infrastructure investment, looking at public finance, governance, urban density, and turning finally to the wider national context.

Table 1: Overall infrastructure spending needs for Africa, 2006-15. \$billion per annum.

\begin{tabular}{|l|l|l|l|}
\hline & $\begin{array}{l}\text { Capital } \\
\text { expenditure }\end{array}$ & $\begin{array}{l}\text { Operation and } \\
\text { maintenance }\end{array}$ & Total needs \\
\hline Transport & 8.8 & 9.4 & 18.2 \\
\hline ICT & 7.0 & 2.0 & 9.0 \\
\hline Water supply and sanitation & 14.9 & 7.0 & 21.9 \\
\hline Power & 26.7 & 14.1 & 40.8 \\
\hline Total & 57.7 & 32.4 & 90.0 \\
\hline
\end{tabular}

Source: Foster and Briceno-Garmendia 2010, Table 1.13

\section{Africa: cities and infrastructure}

The Africa infrastructure deficit needs to be seen in the context of Africa's capital scarcity. In particular, African cities are chronically short of built capital of all sorts - in the stock of housing, in structures devoted to commercial and industrial use, and in the form of public infrastructure.

Up to $80 \%$ of the population in many cities live in informal housing. ${ }^{1}$ This is likely to take the form of single storey shacks, with only limited access to water, sanitation and to electric power. The settlement may be illegal (breaching building and other land use regulations) and tenure may be insecure. Co-existing with this informality are modern houses, often quite large and serving the elite. The striking gap is in the middle: the provision of formal sector decent quality lowincome housing is largely absent in many cities.

Informality is also prevalent in employment, with around $60 \%$ of urban employment taking the form of casual labour and activities such as street trade. Of formal sector employment, much (at least in the capital city) is in the public sector. Private sector activity is oriented to production of non-tradables, generally taking place in very small firms. Again, there is a striking gap: the formal sector employment in the industrial sector that drove much urbanisation in Europe and in Asia is largely missing.

${ }^{1}$ UN-Habitat (2015) estimate that $62 \%$ of Africa's urban population lives in slums, with the number exceeding $90 \%$ in some countries. 
Turning to infrastructure, the provision of public services - ranging from health and education through to water supply and sanitation is generally weak, although better in urban areas than rural. The inadequacy of power supply is widely documented; whereas Africa had three times more generating capacity per person than South Asia in 1970, it now has just half as much (Foster and Briceno-Garmendia 2010). Infrastructure for connectivity will be our focus for the most of this chapter, and the picture is again one of severe under-investment. The density of paved roads in SSA is less than one quarter of that in other low income regions (Foster and Briceno-Garmendia 2010). Within cities, roads are inadequate. For example, roads constitute only around 10 percent of the land area of several large African cities, whereas in a wellconnected large city the figure would be around 30 percent. Freetown is an extreme instance: during a period of state breakdown the city's population grew to over a million as a result of violent disorder in rural areas, but still has little more than the colonial road network designed for a town of 35,000. As a consequence the few roads become highly congested as private users of cars ignore the negative externalities they generate. Crucially, these externalities are not just on other car users, but on buses.

Our central argument is that there are complementarities between these types of investment residential and commercial, private and public. These complementarities create vicious circles, and the possibility of becoming mired in a low level trap. Infrastructure has a key role to play in breaking out of this trap. We explore the mechanisms through which this can happen in the next section, and policy responses in section 4.

\section{Connectivity, infrastructure and urban economic performance}

What is the social value of an infrastructure investment, such as a road or public transport improvement? The direct value is the sum of 'user benefits' created, i.e. the better quality or lower cost service provided to users. Thus, a transport improvement will reduce the generalised transport cost of existing users of the network and also attract (and bring benefit to) new users. Quantification of this is the stuff of standard cost benefit analysis but, we will argue, this significantly under-estimates the value of large scale infrastructure investment, particularly in the urban context.

Cities are, potentially, high productivity areas and drivers of economic growth. The spatial configuration of economic activity in the city is fundamentally dependent on infrastructure, as the investment decisions of firms and households respond to the transport network. Thus, it is hard to imagine London without the underground system, providing 4 million journeys each day and supporting employment densities in central areas in excess of 150,000 workers per square kilometre. While it is evident that infrastructure shapes the city, does this create value over and above the user-benefits of cost-benefit appraisal? In a 'perfect' economy the answer is no: all activities are operating at the scale where marginal benefit equals marginal cost, so any induced 
change in these activities yields no net value. But cities are far from 'perfect' economies. There are myriad non-market interactions, fundamentally the positive one of intense economic interaction, bringing with it agglomeration economies and higher productivity. These interactions work because a high degree of connectivity in the city enables scale and specialization, and the acquisition and transfer of knowledge and skills. This is partly a matter of transport infrastructure (being able to bring 150,000 workers into each square kilometre of the central business district), but also of the wider fabric of the city. High density residential and well-located employment centres support connectivity while economising on transport.

To explore these issues requires a model of economic activity in the city as a whole, and of the determinants of urban economic performance. The conceptual framework we work with is to think of a city's economic performance as the outcome of a trade-off between two forces. One is that cities have high productivity, typically offering higher wages than surrounding areas. This is due, in part at least, to the connectivity offered by cities. The other is that cities are high cost the costs of commuting and congestion, and of high land values and property prices. ${ }^{2}$ What underlies these productivity and cost effects, and how are they shaped by infrastructure?

\subsection{Infrastructure and urban costs}

Poor infrastructure raises the cost of doing business in a city. The consequences of poor power supply are widely documented, and frequently reported by firms to be the major obstacle to growth (Foster and Briceno-Garmendia 2010). The impact of poor road networks and port quality are also cited as major barriers to doing business. ${ }^{3}$

In addition to the direct effect of poor infrastructure on firms' costs, it has an impact on the wellbeing of urban residents, and thence on the attractiveness of the city to migrants from rural areas. The possibility of such migration creates a link between the real incomes of urban dwellers and rural households. ${ }^{4}$ It follows that, if the cost of living in urban areas is high, then nominal wages in urban areas will be correspondingly high. More generally, urban costs can be thought of as a package of the cost of goods and services, together with disutility from poor housing, poor service provision, low quality infrastructure, congestion, and time spent in long commutes to work. Such costs mean that urban wages will have to be relatively high to compensate. Thus, urban areas may have a configuration of low real incomes for workers (set by the supply price of labour from rural areas), but high costs of labour for firms, paying high nominal wages to offset these urban costs. This is a further drag on the competitiveness of firms.

\footnotetext{
${ }^{2}$ This is captured formally in the standard Alonso-Mills-Muth urban model, see e.g. Glaeser (2008).

${ }^{3}$ Although Teravaninthorn and Raballand (2009) also point to the importance of restrictive practises in raising the cost of transport services.

4 Although does not necessarily equate them.
} 
Evidence suggests that this configuration is quite common in African cities. Wages are relatively high (some 15\% higher than in comparable cities elsewhere, at official exchange rates, according to Jones, 2016), but so too is the cost of living. Harati and Nakamura (2016) estimate that the cost of living in African cities is around 20\% higher than cities elsewhere (after controlling for city size, per capita incomes and growth). This is largely due to high housing costs (77\% more expensive than in other cities at comparable levels of economic development). Food prices are also high, partly due to wastage and poor food distribution, a corollary of poor infrastructure. This configuration of prices and wages creates a business environment in which firms can survive supplying non-tradable goods to the local market, but are unable to compete in international markets unless there are offsetting productivity advantages.

A major determinant of urban costs is the efficiency with which the city uses land - its ultimate scarce resource. Efficient land use requires that investors (households and firms) have the confidence to sink capital in constructing long-lived structures. Many factors shape these decisions, and we discuss some of the institutional and governance issues in section 4. Infrastructure evidently plays a direct role. Better transport links create 'user-benefits', improving accessibility to work or amenities and thereby increasing land values and encouraging high density development (e.g. building tall), in order to maximise the return on more expensive land.

In addition to these direct benefits, infrastructure plays an important role in shaping and coordinating expectations about future development. In many circumstances private sector investment is deterred by coordination failure, arising because the profitability of one investment project depends positively on another. It is then not in the interest of any single investor to invest, although each would invest if they knew that others were going to do so. Coordination failures thus lead to low level traps and require some policy mechanism to coordinate individual actions and break out of the trap. A key step in overcoming such a trap is to generate common knowledge of intentions to invest, this being knowledge that is not only widely shared but that is known to be widely shared (Thomas et al. 2014). Infrastructure investment can be such a mechanism for generating common knowledge.

A simple example of this is a growing city in which it is clear to all that a secondary centre somewhere on the edge of the city will be successful, but there is no agreement as to exactly where. The expected return to a private investment in any particular place is therefore low or negative, since this may not turn out to be the place that takes-off. This uncertainty creates the low level trap - no-one invests anywhere. There are different ways to resolve this problem. A sufficiently large private developer could move first, being relatively confident of being followed by other investors. The city authorities can produce an urban plan, selecting areas for development. Or infrastructure can be built. This now has a dual function; it delivers access and user-benefits and is also a credible signal that a particular place will develop. If this resolves the 
coordination failure then the return to the investment can, potentially, be many times greater than the user-benefits alone. This argument applies to transport infrastructure, and also to investment in other services and utilities, such as power supply and water and sanitation.

\subsection{Infrastructure and urban productivity}

The other side of the urban trade-off is high productivity, derived from agglomeration economies. The sources and evidence on agglomeration economies are widely discussed, and so our review is brief. Probably the most important mechanism is that urban connectivity creates an environment where firms and workers can become specialised and reach an efficient scale of operation. The density of customers is large enough that firms can achieve scale, and ease of communication between customers and suppliers makes for product quality and tailored design. Many of the goods and services supplied are intermediates - the specialist components and workers (engineers, lawyers, finance experts) who will raise efficiency in the firms that are their clients. This creates a process of cumulative causation. A new supplier will set up once the market is big enough, and the presence of the new supplier will make the cluster more attractive for firms that use the product or service; this in turn grows the market for specialist suppliers, encouraging further entry. This is the classic process of cluster formation, such as an autoindustry cluster of assemblers and suppliers or a film industry cluster of directors, actors and technicians. There are spillover effects (externalities) in this process. Indivisibilities or increasing returns to scale mean that a service, skill, or product will only be supplied if the market is big enough. The supplier is generally unable to capture all of the benefit, so there is a positive net effect accruing to others in the cluster.

Further mechanisms reinforce this cluster effect. Competition is likely to be intense in a large and dense cluster so monopolistic pockets of inefficiency are less likely to survive. Monopsonistic behaviour, occurring where there are few potential purchasers for a product or skill, can deter investment; this too is less likely to be a problem in a large and dense cluster. There may be direct knowledge spillovers between firms, as 'mysteries of the trade become no mysteries; but are as it were in the air' (Marshall 1890). Each of these mechanisms may operate within particular sectors or across a wide range of sectors, the former being referred to as localisation (or Marshallian) economies, and the latter as urbanisation (or Jacob) economies. Within-sector productivity effects create a force for sectorally specialised clusters and possibly specialised cities. This is important in some manufacturing sectors; developed country manufacturing exhibits automotive clusters, and developing country manufacturing contains clusters in labour intensive sectors such as textiles and garments. Clustering is particularly prevalent in business services such as finance, law, and media. Both the creation and diffusion of knowledge work particularly well in clusters, and a large body of literature points to the spatial concentration of innovative activities. 
The magnitude of these agglomeration effects has been extensively researched, although largely in developed economies. A reasonable consensus has emerged on the magnitude of effects. An authoritative (although quite old) survey of the literature finds that 'in sum, doubling city size seems to increase productivity by an amount that ranges from roughly 3-8\%' (Rosenthal and Strange 2004). This implies that the elasticity of productivity with respect to city size is in the range $0.05-0.11 .^{5}$ This is a large effect in the cross-section, suggesting that productivity in a city of 5 million is between $12 \%$ and $26 \%$ higher than in a city of $1 / 2$ million. A meta-study (Melo et al. 2009) suggested that the mean estimate of this elasticity across several hundred studies is somewhat lower, at 0.03 , although finding considerable variation according to sector, country, and technique employed by researchers. Recent work using individual data (and controlling for individual effects) produces estimates of similar magnitude. At the sectoral level, there is evidence of heterogeneity, with business services and high technology sectors exhibiting the largest localisation economies.

The critical point about these mechanisms is that they all depend on connectivity - the ability of firms to connect with many customers and suppliers and draw on large pools of workers. Good transport infrastructure enables a city to achieve connectivity, and does so in two distinct ways. One is that, given the levels and location of employment, intra-city connectivity is enhanced so that firms are able to communicate with each other, and workers can get to jobs. The other is that, since the location becomes a more attractive destination for investment, the overall scale of the city, and any clusters within it, will be larger. A positive feedback applies, as higher levels of activity raise productivity, making the city a still more attractive place to do business. ${ }^{6}$

\subsection{Outcomes}

The arguments above suggest that urban infrastructure brings down costs faced by firms, making the city a more attractive place for inwards investment. Furthermore, infrastructure that increases connectivity enables scale and specialisation and so raises productivity. In the absence of good transport infrastructure complex economic activity is not possible as communication between firms gets obstructed and individuals cannot get to work in concentrated areas of employment. In consequence, a city that lacks connectivity cannot achieve agglomeration benefits or generate high-productivity jobs.

The forces we have described can generate cumulative causation process and multiple equilibria, some desirable, others highly dysfunctional. ${ }^{7}$ The virtuous circle is that infrastructure investment and other policies bring down urban costs and raise and coordinate expectations; investment

\footnotetext{
${ }^{5}$ Elasticities are therefore in the range $0.05-0.1$ since $2^{0.05}=1.03$ and $2^{0.11}=1.08$.

${ }^{6}$ This is recognised in transport appraisal in some countries (including the UK), which factors in 'wider economic benefits' that are generated by the density, scale, and productivity enhancing effects of transport improvements.

${ }^{7}$ See Venables (2016b) for formal development of this argument.
} 
follows, this bringing agglomeration economies and raising productivity; in turn, this raises income and land values, providing the tax base to fund the infrastructure (to be discussed further in the next section). The vicious circle is the converse of this, with the low infrastructure, high cost, low employment outcome that we described earlier.

The consequence is very divergent performance of developing cities around the world. Many Asian cities - in East Asia, and increasingly now South Asia - have been able to attract and grow the sectors that are prone to agglomeration economies. In contrast, most African cities are 'artisanal cities', characterised by low levels of investment in infrastructure and low levels of residential and business investment. Such cities have inefficient land use, lacking density and so further impeding connectivity. They are relatively high cost and low productivity, making them unattractive locations for internationally mobile investment in tradable sectors, as a consequence of which that they fail to achieve agglomeration and urbanisation economies. This is apparent in the evidence on industrial composition. The share of manufacturing in African countries as a whole is low, and there is some evidence pointing directly to the share of tradable activities in urban areas. For example, looking just at firms with more than 20 employees, less than $50 \%$ of employment in Dar es Salaam, Kampala, Kigali and Lusaka is in tradable activities, while in a sample of similar size Indian cities, the figure is more than $80 \%$ (Jones 2016).

\section{Policies for the Infrastructure of Connectivity}

The previous section indicates that improvements in connectivity need to be evaluated in terms of their city-wide impact, and may have benefits over and above the user-benefits of standard cost benefit analysis. This evaluation poses technical challenges, although methodologies exist for quantifying some effects. For example, the appraisal methodology in England and Wales quantifies 'wider economic benefits' accruing from agglomeration and from land-use change. ${ }^{8}$ In developing economies the policy challenge is wider. We begin with two key sets of policies that shape urban connectivity: the generation of public revenues to finance investments in urban infrastructure and the promotion of investment in housing sufficient to enable high levels of urban density. We then turn to the meta-policy of creating an authorizing environment for cities that is conducive to these policies. Finally, we set out the scope for linking resource extraction to the provision of national connectivity.

\subsection{Infrastructure and urban public finance}

\footnotetext{
8 These are reviewed in Venables (2016a). For details see Department for Transport (2013) and for principles see Venables (2007).
} 
How is urban infrastructure to be financed? As we saw, the scale of expenditure is daunting, often amounting to 10-20\% of urban GVA. However, economic principles and the experience of some cities indicate that there is a readily available tax base that can yield sufficient revenue to meet these expenditures: land values.

Land values have many advantages as a tax base, as noted by economists back to Ricardo and popularised in the writings of Henry George and his followers. The appreciation in value of a particular piece of urban land is not due to the actions of the land-owner, but due to its location in the city and thence the collective activity of the city including provision of urban infrastructure. The equilibrium response of land prices to a transport investment will generally mean that 'user-benefits' end up being passed from transport users to landowners. For example, a new subway station makes nearby houses more desirable so rents will increase. In the simplest cases (either a perfectly elastic demand curve for housing or a perfectly inelastic supply of housing in each place) all of the 'user-benefit' of the improvement is bid away by higher rents, which are in turn capitalised in higher land values.

This has two implications. First, taxation of land values is non-distortionary. Land is in fixed supply, immobile, and earns pure economic rent, so taxing it does not distort economic decisions and induces no micro-economic inefficiency. Second, it is ethically well-grounded, since the land-owner has no moral claim to have earned the appreciation in value. The appreciation is due to collective action in the city, making a case for returning it to the city to finance collective urban spending.

Furthermore, urban land value is usually sufficient to finance all the public goods needed in an efficient city. Arguments making this point are sometimes referred to as 'Henry George theorems' and come in several forms. ${ }^{9}$ In a developing country context the basic idea is simple. If the city draws in workers from outside at some exogenously given rural wage, then the entire economic surplus created by the city accrues to its scarce factor, land. Since it cannot be efficient to invest more in infrastructure than the total surplus it creates, tax at some rate less than $100 \%$ is sufficient to finance all infrastructure needs.

However, an important issue concerns the mismatch between the timing of expenditure on infrastructure and that of the generation of tax revenues. Many infrastructure investments have to be made as a city is growing and are prohibitively expensive to retrofit, but revenue from a continuing tax on land value accrues over the entire life of the city. Some of these future tax revenues therefore need to be capitalised to finance up-front investments. This is easy if the state (or the city) initially owns the land and can sell it for development as the city grows. Thus, land in Hong Kong was owned by the crown (i.e. the UK government) and sale of crown lands

${ }^{9}$ See Arnott and Stiglitz (1979) for a formal statement of Henry George theorems. 
financed the development of the city. Chinese cities have been able to finance growth (and, in some cases excessive infrastructure spending) by selling land to developers (World Bank 2014). In Africa, however, urban land is seldom publicly owned so that investment in infrastructure requires borrowing. This need not be problematic as long as the urban tax base is built to provide future tax revenues as implicit collateral, although in practise this has not been credibly pursued.

In addition to raising revenue, land value taxation also has the effect of reducing the costs of land purchase required for infrastructure investment. Due to the lack of public ownership and the political power of landowners, land that has to be acquired will typically be bought at market valuation. Whereas in the OECD compensation for compulsory purchase is conventionally made at values prior to the announcement of infrastructure development, in Africa courts commonly set it simply at prevailing market prices. Further, since many African urban infrastructure

projects are partially funded by aid, donor concerns for respecting human rights require a right of appeal to the courts. Hence, the more socially valuable the infrastructure, the more costly it will be to install. Market values are further inflated, partly because land is untaxed, and partly because the recorded transactions on which court valuations are based is for land which has uncontested rights of ownership and vacant possession and this is scarce.

Administratively, a tax on land value is relatively undemanding. The start is to gather data on the price at which land is being transacted, and to use this to map the city into zones according to bands of land prices. For example, the central business district (CBD), would be the highestprice zone. The next step is to build a cadastre delineating plots linked to a public register showing all the claims of ownership of these plots. In many cities ownership is contested but this need not impede building a register: on the contrary, it makes one even more useful. By promulgating a simple law that sets a date by which all claims to urban land must be registered in order to be considered valid, a register would both flush out and limit the extent of land disputes. Further, a land tax can be designed so as to create an incentive for dispute resolution. Each claimant to a plot can be made liable for the full tax on the plot, so that the parties to a dispute can reduce their combined tax bill be settling it.

Constructing such a register brings with it other benefits, most notably enabling property transactions and the use of land as collateral. The tax is best levied simply on the annual ownership of land, rather than on either the property built on it, or transactions. Taxing property discourages investment in structures, and taxing transactions discourages changes of land use, both of which would be distorting. In contrast, an annual tax on land ownership encourages owners of underutilised land to sell it to those who could use it more productively.

\subsection{Infrastructure and residential density}

Density is a substitute for transport infrastructure in generating urban connectivity. Achieving connectivity in a sprawling city requires a massive road network, but a dense city can get away 
with a much smaller and cheaper network. Further, density enables advanced high capacity transport technologies which support the very high levels of connectivity common in major cities of the OECD. Technologies such as Bus Rapid Transit, Light Rail and Metros become viable only if there is sufficient density of passengers. Hence, density, both residential and commercial, is a public good.

Table 2: Capital costs per capita of infrastructure provision, by density. \$ per capita

\begin{tabular}{|c|c|c|c|c|c|c|c|c|c|}
\hline \multirow{2}{*}{$\frac{\text { Infrastructure type }}{\text { Density (people/km²) }}$} & \multicolumn{6}{|c|}{ Large cities } & \multirow{2}{*}{$\begin{array}{c}\begin{array}{c}\text { Secondary } \\
\text { cities }\end{array} \\
1,247\end{array}$} & \multirow{2}{*}{$\begin{array}{c}\begin{array}{c}\text { Rural } \\
\text { hinterland }\end{array} \\
38\end{array}$} & \multirow{2}{*}{$\begin{array}{c}\begin{array}{c}\text { Deep } \\
\text { rural }\end{array} \\
13\end{array}$} \\
\hline & 30,000 & 20,000 & 10,000 & 5,008 & 3,026 & 1,455 & & & \\
\hline \multicolumn{10}{|l|}{ Water } \\
\hline Private tap & 104.2 & 124.0 & 168.7 & 231.8 & 293.6 & 416.4 & 448.5 & $1,825.2$ & $3,156.2$ \\
\hline Standpost & 31.0 & 36.3 & 48.5 & 65.6 & 82.4 & 115.7 & 124.5 & 267.6 & 267.6 \\
\hline Borehole & 21.1 & 21.1 & 21.1 & 21.1 & 21.1 & 21.1 & 21.1 & 53.0 & 159.7 \\
\hline Hand pump & 8.3 & 8.3 & 8.3 & 8.3 & 8.3 & 8.3 & 8.3 & 16.7 & 50.4 \\
\hline \multicolumn{10}{|l|}{ Sanitation } \\
\hline Septic tank & 125.0 & 125.0 & 125.0 & 125.0 & 125.0 & 125.0 & 125.0 & 125.0 & 125.0 \\
\hline Improved latrine & 57.0 & 57.0 & 57.0 & 57.0 & 57.0 & 57.0 & 57.0 & 57.0 & 57.0 \\
\hline Unimproved latrine & 39.0 & 39.0 & 39.0 & 39.0 & 39.0 & 39.0 & 39.0 & 39.0 & 39.0 \\
\hline \multicolumn{10}{|l|}{ Power } \\
\hline Grid & 63.5 & 71.2 & 88.5 & 112.9 & 136.8 & 184.3 & 196.7 & 487.7 & 943.1 \\
\hline Minigrid & 87.6 & 95.2 & 112.5 & 136.9 & 160.8 & 208.3 & 220.7 & 485.8 & 704.2 \\
\hline Solar photovoltaic & 92.3 & 92.3 & 92.3 & 92.3 & 92.3 & 92.3 & 92.3 & 92.3 & 92.3 \\
\hline \multicolumn{10}{|l|}{ Roads } \\
\hline High quality & 31.6 & 47.4 & 94.7 & 189.2 & 313.1 & 651.3 & 759.8 & 269.1 & 232.4 \\
\hline Low quality & 23.6 & 35.4 & 70.7 & 141.2 & 233.8 & 486.3 & 567.3 & 224.3 & 193.6 \\
\hline \multicolumn{10}{|l|}{$I C T$} \\
\hline Constant capacity & 1.1 & 1.7 & 3.3 & 6.6 & 10.9 & 22.8 & 26.6 & 39.8 & 129.7 \\
\hline Actual capacity & 1.1 & 1.7 & 3.3 & 6.6 & 10.9 & 22.8 & 26.6 & 129.7 & 422.1 \\
\hline \multicolumn{10}{|l|}{ Total } \\
\hline Variable quality $y^{3}$ & 325 & 369 & 480 & 665 & 879 & 1,031 & 1,061 & 940 & 836 \\
\hline Constant (high) quality ${ }^{b}$ & 325 & 369 & 480 & 665 & 879 & 1,400 & 1,557 & 2,837 & 4,879 \\
\hline
\end{tabular}

Source, Foster and Briceno-Garmendia 2010, Table 5.6

The magnitude of savings in the cost of infrastructure that density permits is indicated in table 2 . Per capita costs of providing the package of infrastructure measures given in the table decline strongly with the density of settlement: capital costs per capita vary from nearly $\$ 5,000$ in deeply 
rural areas, to only $\$ 325$ at very high urban density. While sanitation infrastructure has constant returns, the cost of transport is best approximated by land area served, so falls in inverse proportion to population density. ${ }^{10}$

Currently, African settlement is characterized by very low density: over half the population is rural. Fortunately, rapid urbanization is increasing the population-weighted national density of settlement. However, offsetting this, within cities density is low. Cities are growing through sprawl because people live overwhelmingly in single-storey informal housing. The infrastructure capex cost to accommodate these new urban residents is consequently acutely sensitive to the density at which urbanization occurs. With Africa's urban population growing at around $15 \mathrm{mn}$ people per annum, the cost implications of different urban densities are huge, ranging from $\$ 15 \mathrm{bn}$ pa at the density currently typical of secondary cities, down to around \$5bn pa at the highest densities. Hence, cost effectiveness implies prioritizing urban infrastructure to facilitate rapid urbanization, and within urban areas encouraging higher density.

These factors suggest that a key element of infrastructure policy is pursuit of a wider package of policies to increase the density of settlement in African cities. ${ }^{11}$ Africa's cities have low density primarily because residential structures are predominantly single-storey shacks. This is the consequence of policy failure surrounding three key issues which we consider in turn.

\section{Affordability}

Affordability can only be assessed relative to income. Quite what this implies for a viable purchase cost depends upon the real interest rate and the terms of financing, but a likely ceiling for low-cost housing is around $\$ 15,000$ including the price of land. The unit costs of house construction depend partly upon building standards, partly upon costs of inputs, and partly upon the organization of the construction industry.

All cities need building standards and it is appropriate for standards to anticipate rising income. However, it is also important to anticipate the need for rising density. If the regulation of building standards is appropriate, they provide a mental shorthand reducing decision costs. However, in 1947 Britain substantially raised standards (the Parker-Morris standards) and implemented them across the Empire. Hence, upon Independence African governments inherited

\footnotetext{
${ }^{10}$ For comparison, large S. Asian cities have densities in excess of 20,000 people per $\mathrm{km}^{2}$, Lagos has 14,000 and typical African capital cities in the range 5-8,000, similar to London at 6,000 (Demographia 2015).

${ }^{11}$ This section draws on Collier and Venables (2015)
} 
regulations that were inappropriate for the level of income. For example, in Nairobi the minimum legal plot size is $1 / 16^{\text {th }}$ of an acre, which is unaffordable for ordinary households. Not only were these not revised downwards, they conveyed the impression to African regulatory authorities that modernization would require standards to be raised from time to time. Hence, for example, in Dar es Salaam the minimum size of plot is $500 \mathrm{~m}^{2}$, but the authorities are discussing whether to raise it to $700 \mathrm{~m}^{2}$. How out of line were the British standards of the 1947 for the level of African incomes? In purchasing power parity terms African per capita income is less than one 20th of British incomes as of 1970. Evidently, these standards will not become appropriate until long after the housing has been replaced. The consequence of unaffordability was inevitably that housing construction has bifurcated, with regulations being ignored in the informal market that caters for ordinary households. But informality brings other costs. Designs are idiosyncratic and foundations unobservable, and so properties are hard to value. Being hard to value impedes the resale market, and its use as collateral.

Poor regulation has also added to the cost of material inputs such as cement, which in Africa is typically around three times the world price. Importation and domestic supply have been subject to local monopoly. For example, Aliko Dangote, the richest individual in Africa with a fortune estimated at $\$ 11 \mathrm{bn}$, founded his business empire on cement imports to West Africa.

Building standards and high input costs have bifurcated the organization of the construction industry. While elite homes are constructed by foreign construction companies, ordinary urban housing is largely self-built to ad hoc personal designs. This sacrifices the potential for economies of scale and specialization, and rules out the key designs for density such as townhouses and multi-storey flats.

\section{Legal Rights}

Legal rights affect the housing market in three respects: the ownership, security and marketability of land rights; the extent to which housing can function as collateral; and the rights of tenants relative to landlords.

African urban land rights are confused and contested. Claims to legal title jostle in corrupt courts and compete with informal de facto possession. The same piece of land may have several claimants each supported by some sort of documentation: the number of claimants increases in response to construction since ownership becomes more valuable. Since high residential density requires investment in multi-storey construction, weak land rights evidently impede it. They also delay changes in land use to higher density by impeding transactions.

Clarity in plot rights, though necessary for property to function as collateral, is not sufficient. The function of collateral depends upon the ability of a creditor to foreclose on the property in 
defined circumstances of arrears. This in turn depends upon the law, and the reliability and speed with which courts implement it. The common experience has been for delays in court proceedings and judicial corruption to make foreclosure unreliable. However, reform is feasible. Ethiopia has recently introduced draconian legislation that is being enforced in its courts whereby creditors can foreclose after only a few months accumulation of mortgage arrears.

Tenancy will be the affordable option for most urban households. In much of urban Africa, while there is a well-functioning formal rental market for expatriates, that for ordinary households has largely informalized in response to generous tenant protection. For example, in Nairobi tenants with rent of less than $\$ 60$ per month have enhanced rights and landlords cannot raise rents.

In summary, the confused nature of urban land rights in Africa reflects the recent nature of African urbanization and the very slow and confused evolution of rural land rights. In societies with few other assets and a long and recent attachment to the soil, land rights are inevitably politically sensitive; governments have lacked sufficient legitimate authority to resolve them. This contributes to the lack of investment in housing, leaving ordinary households in singlestorey dwellings, crowded but not dense.

\section{Financial Innovation}

In $19^{\text {th }}$ century Britain urbanization triggered innovation in the mortgage market through building societies. They were able to out-compete banks because they had lower administrative costs and lower risks and so could work on narrower spreads. The setup costs of a loan could be spread over many years and default was limited by good collateral. Not only were spreads low, but in $19^{\text {th }}$ century Britain inflation was very low, so that nominal interest rates could be low. Building societies were also able to build a large deposit base from ordinary savers.

Although some African cities have building societies, they cater to either high-end housing or to civil servants. Except in the Franc Zone inflation is periodically fairly high, so that on conventional interest rate practices the principle is at times rapidly eroded. Typical terms on African 'affordable' mortgages are an interest rate of 22 percent and a term of only ten years. Unsurprisingly, defaults are concentrated in the first two years of the loan when in real terms repayments are at a maximum. The upshot is that mortgages only cater to a tiny elite: around three per cent of households. Hence, in Africa the normal financial engine of investment in residential structures is not able to function.

A common policy response has been to place ceilings on interest rates, or to offer subsidized public mortgages. For example, the Nigerian government has been providing mortgages at 6 percent at a time when the market interest rate is 18 percent. Evidently, this is not fiscally viable at any scale. A more viable policy might be to introduce indexation of mortgages, enabling 
repayments to be stretched over a much longer period. There may also be scope for building societies to mobilise untapped savings through the new techniques of e-banking, as has been pioneered in Kenya. By matching the indexation of their mortgage assets with the indexation of their deposit liabilities building societies could have a safer business model. It is important for housing finance to attract domestic savings because, not being an export sector, it would expose foreign finance to an exchange rate risk that would require a corresponding level of interest rates.

For housing to function as low-risk collateral, building societies need the conditions discussed above. Legal title would have to be clear, and court processes reliable. Formal housing would need to be affordable, of standard design, and built to enforced standards, so that it could readily be valued.

\subsection{Governance for urban infrastructure}

Around the world, many cities provide the connectivity that enables high productivity along with the social infrastructure for liveability. But most cities in poor countries provide neither. This dramatic and persistent manifestation of multiple equilibria demands explanation.

To some extent, the deficiencies in policy reflect deficiencies in knowledge among the politicians and civil servants responsible for them. Pertinent research evidence is limited because until very recently development economists have paid little attention to urbanization. Quantitative spatial analysis is very data-demanding, and for poor countries such data have not been available. New techniques such as the analysis of military satellite images are just opening up the research frontier. The overwhelming emphasis of research has been either on national policies such as industrialization and education, or on rural poverty, a topic better suited to randomised control trials. Not only is there a deficiency in research, urban issues seldom reach the top of government. This is partly because good urban policies require long-term thinking, whereas the pressures of democratic politics in poor societies have favoured short horizons. But it is also because the development agencies that strongly influence policy agendas have prioritized social and macroeconomic issues. For example, in the World Bank, urban policies have been just a sub-branch of one among numerous thematic Vice-Presidencies.

However, policy deficiencies predominantly reflect failures of governance. Partly this is because the policies discussed above have been blocked by powerful special interests. For example, a key transport policy at African levels of income is to introduce bus lanes that provide privileged road access for mass transport. Otherwise, private vehicle use drastically reduces the connectivity value of roads. But African urban authorities are reluctant to offend the small minority of households rich enough to own a car. Even among car owners, the rich tend to get priority. For example, at one stage the city authority of Lagos reduced congestion by banning cars registered 
with odd and even number plates on alternate days, enabling the richest to evade the control by purchasing two cars.

Special interests are also responsible for the confused state of urban land rights, which we have suggested is hugely damaging. In most countries the ownership of urban land is politicized. Powerful people such as politicians and senior civil servants have used their positions to establish some claim to legal title. Corruption in the courts adds a further layer of confusion since it invites contestation even within elites: around $80 \%$ of African court cases are about contested land ownership. But such legal titles, often with dubious histories, are usually insufficient to enable the eviction of those who occupy the land without title and so have de facto possession: African elites like the courts but fear the streets. This produces a stalemate in which low-value uses of inner city land such as low-density shack housing persist, with the owners of legal title extracting rents well below the level implied by the valuation of the relatively few parcels of land that have both uncontested title and vacant possession. For example, Henderson et al (2016) estimates the cost of land underutilization in the Nairobi slum district of Kibera at \$1.8bn.

But the potential gains left unrealized are so large that vested interests are unlikely to be the predominant explanation: why, for example, has the massive potential gain from changes of use in Kibera not led to mutually beneficial solutions? Ultimately, such failures of governance reflect weaknesses in the structure of authorizing environments: either nobody has the authority necessary for action, or it is dispersed among so many actors that the coordination required is unmanageable. This has occurred because the pace of urbanization has exceeded the capacity of governments to redesign the local structures of political authority. Colonial cities were tiny; since them most cities have sprawled so rapidly that they span several units of local government. The resulting coordination problem is compounded because the delineation of authority is unclear both between local and national government, and between numerous ministries within national government. Practical authority is highly concentrated in Presidencies and Ministries of Finance, but this creates a logjam of policy disputes awaiting resolution among low-ranking and disputed issues such as urbanization.

Where presidential authority is committed to making cities efficient, vested interests can be surmounted and the situation can rapidly change. For example, in 2011 President Museveni of Uganda converted the governance of Kampala from the conventional structure of a local council and a mayor, to the status of a national ministry, headed by a technocrat whose first act was to re-staff the administration. Similarly, in Rwanda presidential authority has enabled the creation of a definitive national register of land ownership.

In Africa authority is disproportionately concentrated in the presidency. Historically, successful urbanization in the OECD benefited from power being decentralized to cities. In East Asia, 
China has had a similarly decentralized approach, albeit not a democratic one, while the global benchmarks for successful urbanization, Singapore and Hong Kong, are city-states. Given the structure of political authority in Africa, the most credible solution is to elevate the salience of urbanization to presidencies. As the above examples illustrate, only presidential authority can break the impasse that has characterized policy. With its demographics delivering a bulge of young workers heading for cities, and with commodity markets delivering a collapse in the profitability of resource extraction, harnessing the productivity potential of urbanization is no longer one issue among many. It has become the decisive strategy of the coming decade. Building a strong evidential basis from research may become critical both in shifting the agenda of the development agencies, and in convincing presidents that a fundamental change of approach is imperative.

\subsection{Infrastructure for national connectivity: economies of scope in resource extraction}

Africa is a vast continent with very poor national connectivity. Post-Independence, the provision and maintenance of national transport infrastructure proved to be prohibitively expensive for governments with weak tax systems and high demands for other spending. Domestically, the resulting wide wedge between on-farm food prices and urban prices contributed to the secular trend whereby cities are often fed predominantly from imports. Internationally, since in most countries exports are overwhelmingly commodities produced in rural locations, it contributed to export underperformance. The resource boom of 2004-14, which stimulated new discoveries, both increased the need for connectivity to global markets, and provided a rare opportunity for achieving it.

Consider a geologically virgin territory typical of a poor country where a prolonged history of mis-governance has severely curtailed prospecting. The only known prospect, known because it is so spectacular, is a massive deposit of a bulk mineral located in a remote area. This has never been exploited because mis-governance ruled out the massive investment that would have been required. Now, for the first time in the country's history, the combination of a global commodity boom and improved governance has transformed the investment into commercial viability. A company negotiates with the government and acquires the right to exploit the mineral. The question now to be negotiated is the regulatory structure for the rail-port facility that will be required.

In this situation, the mining company is rightly wary of being subject to a hold-up problem should control of the railway be distinct from that of the mine. It argues that the mine and the rail are a single integrated operation and should therefore be viewed as a single commercial entity. However, the railway has the potential to serve other users as well as the mine. It traverses the country and so could be the backbone of a future national rail network. Building the railway so as to be capable of meeting this potential would involve additional cost and divert the company from its core business of mining resources and so its preference is to build the infrastructure for 
dedicated use. Appropriate regulation has the potential to transform the railway into a valuable national asset.

Suppose that from the overall perspective of the society the extra cost of building the facility for multiple functions, thereby turning it into a transport corridor, would be far outweighed by the likely future benefits. The government can require this, while indirectly shouldering the extra costs through offering the company more generous terms of taxation. The future users cannot be ascertained because until the rail is open to them the normal process of trial and error by which opportunities are established cannot get underway.

Crucially, an important class of such opportunities is the extraction of other mineral deposits. Once the rail exists, the terms on which it can be used will determine whether other prospectors choose to invest in search. If the initial mine retains private monopoly rights over the rail it has the power of hold-up over all such potential users of the mine. In particular, should another company incur the sunk costs of exploration and discover a highly valuable deposit, the owner of the railway can set terms of usage that extract not only the entire rents on the discovery, but even the value of the sunk costs. Evidently, since a potential prospector is aware of this power before investing, the negotiation as to the terms of rail usage will occur prior any investment in search, but even at this stage the rail owner is in a position to extract the entire expected rents from exploration. This places the rail owner in direct competition with the government. Normally, the rents from exploration would accrue to government, for example through a sequential process of auctioning prospecting rights as the territory is gradually opened up to commercial mining activity. The rail owner can entirely pre-empt these rents through a prior negotiation process with potential bidders. No company can know how much it is worth bidding for prospecting rights until it has reached a deal with the rail company on the costs of usage. Equivalently stated, the only credible bidder for these subsequent prospecting rights is the company that owns the railway, and knowing itself to be the sole bidder it has no incentive to pay other than token amounts for these explicit rights. It already owns the implicit rights.

Hence, in the absence of regulation, the natural monopoly dictated by the network economies of a major railway imply that the owner of the railway acquires the expected value of all future mineral discoveries covered by the rail network. The potential scale of the rail network cannot be ascertained until the discovery process has played out, so the potential value of the rents is a classic instance of uncertainty as distinct to risk: no meaningful number can be placed on it. As such, it is better to leave this uncertain value with the society that to allow it to be sold to the company that purchases the original mining concession as a potentially large part of the implicit value of its explicit mining rights. Otherwise, the company is acquiring both the explicit rights to exploit the known deposit and the implicit right to the entire undiscovered resource endowment covered by the potential future rail network. This second component of its acquisition is of such uncertain value that it is unlikely significantly to bid up the price that the company is willing to pay for its explicit mining rights: there is insufficient information to provide the basis for a commercial valuation that could meet the requirements of an audit. 
In effect, unless the government insists that the railway should have clearly specified open access terms, this initial sale of rights hands over a great swathe of future mining rights to the company. Because an inherent transport monopoly is interdependent with a prospecting process that is intrinsically sequential, regulation to enforce open access is essential. The public interest is overwhelmingly in favour of the preservation of competition for prospecting rights: only competition can ensure that it is the government rather than the monopolist that acquires the rents from natural resource exploitation. In poor countries, since the mining companies are foreign, the social capture of rents is the key means by which the society can benefit from extraction. The situation described above, in which the construction of rail or port infrastructure for a particular deposit precedes systematic search over the territory that is potentially served by the infrastructure, is typical of an entire class of country and so appropriate rules of governance for that infrastructure are an important matter. ${ }^{12}$ Africa's largest mining project, the Simandou iron ore mine in Guinea which is currently underway, is an example of a negotiation in which this issue has been central.

Similar issues arise with other infrastructure with the potential for shared use, such as national networks for mobile phones, where a substantial part of the investment cost is the provision of towers. As with rail, this provides the potential for private monopoly. With good regulation, the business of operating the network of towers can be split off from that of mobile phones, owned by an independent tower operator. The operator sells shared use to the phone companies on equal terms.

While the case for regulation to require open access to private rail networks is analytically clear, it has seldom been made operative in Africa. More typically, companies have negotiated deals that provide some quick finance, but finesse operating complexities.

\section{Conclusion}

In poor countries, radical improvements in connectivity, both urban and national, are critical for the higher productivity that is the essence of development. The investment costs of providing this enhanced connectivity far exceed the potential for aid finance. International private finance is unlikely beyond that needed for resource extraction. With the end of the commodity boom and the flight of international capital to safe assets, the scope for sovereign borrowing which briefly opened in 2010, is again severely limited. Hence, it is important that connectivity be improved by alternative ways of raising revenue, and means that minimize the cost of infrastructure. We have suggested three complementary approaches.

\footnotetext{
${ }^{12}$ For a fuller treatment see Collier and Ireland (2016).
} 
First, urban public finance needs to be put on a sound footing by the introduction of land and property taxation. This is equitable, efficient and administratively feasible. But as with all tax raising measures, it takes political authority to introduce and implement.

A second approach is to raise density, since density has the potential to radically reduce per capita infrastructure costs. We have discussed two sets of policies that could raise density. By prioritizing transport infrastructure for urban connectivity, population-weighted national density could be dramatically increased. It could also be increased through raising residential density within cities by a series of measures to improve the operation of housing and urban land markets.

The other is to piggyback national infrastructure onto the private investments in resource extraction that have been triggered across Africa by commodity boom. Although that boom is over, the horizon for investment in mineral extraction is typically several decades, and so less sensitive than sovereign lending to current prices.

None of these policies are currently common in poor countries, and certainly not in Africa. Governments have been fearful and neglectful of urbanization. Urban transport infrastructure has been underprovided, and investment in residential density has been negligible. In consequence, Africa's cities have very poor connectivity and so have not attracted internationally traded economic activities. Similarly, to date, investment in rail and ports for resource extraction has almost invariably been for dedicated use by individual companies.

In the heady days of the commodity booms and the slogans about 'Africa Rising', governments may have been lulled into a sense of confidence that infrastructure needs would be met externally. It is now time for infrastructure to become a serious priority of domestic policy, through solutions that are smart and parsimonious.

\section{References}

Arnott, R.J. and J.E. Stiglitz, (1979) "Aggregate Land Rents, Expenditure on Public Goods, and Optimal City Size," The Quarterly Journal of Economics, 93(4), 471-500.

Collier, P. and G. Ireland, (2016), 'Shared-Use Mining Infrastructure: Why it Matters, and How to Achieve it', Development Policy Review (forthcoming).

Collier, P. and A.J. Venables (2015), 'Housing and urbanization in Africa: unleashing a formal market process', in E. Glaeser and A. Joshi-Ghani (eds) The urban imperative; towards competitive cities, OUP, Oxford.

Demographia World Urban Areas (2015), http://www.demographia.com/db-worldua.pdf

Department for Transport (2013) 'Transport analysis guiudance: WebTAG' , https://www.gov.uk/guidance/transport-analysis-guidance-webtag 
Estache, A., T. Serebrisky and L. Wren-Lewis (2015), 'Financing infrastructure in developing countries', Oxford Review of Economic Policy, 31 (3-4): 279-304

Foster, V. and C. Briceno-Garmendia (2010) 'Africa's infrastructure; a time for transformation', World Bank, Washington DC.

Glaeser, E. (2008), 'Cities, Agglomeration and Spatial Equilibrium', Oxford: Oxford University Press.

Harati and Nakamura (2016)

Henderson, J.V., T. Regan and A.J. Venables (2016) 'Building the city; sunk capital and sequencing', processed, LSE

Jones, P. (2016)

Marshall, A. (1890), 'Principles of Economics', Macmillan, London.

Melo, P.C., D.J. Graham and R.B. Noland (2009) A meta-analysis of estimates of urban agglomeration economies, Regional Science and Urban Economics, 39, 332-342.

Rosenthal, S. S. and Strange, W. C. (2004) Evidence on the Nature and Sources of Agglomeration Economies. Handbook of Urban and Regional Economics, Vol. 4, ed. Henderson, J. V. and Thisse, J. F. New York: North-Holland.

Teravaninthorn, S and G. Raballand, (2009). Transport Prices and Costs in Africa: A Review of the International Corridors. World Bank, Washington, DC .

Thomas, K., O.S. Haque, S. Pinker and P. DeScioli, 2014, The Psychology of Coordination and Common Knowledge, Journal of Personality and Social Psychology, 107, 657-676.

UN-Habitat (2015) 'World Atlas of Slum Evolution', http://unhabitat.org/world-atlas-of-slumevolution/

Venables, A.J. (2007) 'Evaluating urban transport improvement: cost benefit analysis in the presence of agglomeration and income taxation' Journal of Transport Economics and Policy, 41 (2007), 173-188.

Venables, A.J. (2016a) "Incorporating wider economic aspects within cost-benefit appraisal", Discussion Paper 2016-05, International Transport Forum, OECD, Paris. http://internationaltransportforum.org/jtrc/DiscussionPapers/incorporating-widereconomic-impacts-cba.pdf

Venables, A.J. (2016b) 'Breaking into tradables: urban form and urban function in a developing city', processed Oxford.

World Bank (2014) 'Urban China: toward efficient, inclusive and sustainable urbanisation', The World Bank and the Development Research Center of the State Council, P. R. China, Washington DC. 